\title{
DUKUNGAN SOSIAL YANG MENDORONG PERILAKU PENCEGAHAN SEKS PRANIKAH PADA REMAJA SMA X DI KOTA SURABAYA
}

\author{
SOCIAL SUPPORT WHICH ENCOURAGE PREMARITAL SEX BEHAVIOR \\ IN SENIOR HIGH SCHOOL X ADOLESCENTS IN SURABAYA
}

\author{
Chitra Diana Rahmawati, Shrimarti Rukmini Devy \\ Departemen Promosi Kesehatan dan Ilmu Perilaku \\ Ikatan Alumni Kesehatan Masyarakat Indonesia \\ Fakultas Kesehatan Masyarakat Universitas Airlangga \\ Email: chitra.dier@gmail.com
}

\begin{abstract}
The number of premarital sex among adolescents have been increasing. Based on BKKBN's report (2014), 46\% of adolescents aged 15-19 years old already had premarital sex experience. Therefore, it requires preventions to solve adolescents' premarital sex problems. This study aims to identify social support to preventive efforts against premarital sex of high school students X in Surabaya. This descriptive study used qualitative research design and purposive sampling technique to determine the number of sample. Indepth interviewed conducted on 32 informants that were consist of 10 students, 10 close friends, 10 parents and 2 teachers. The results showed that social support especially from families who provide religious education, contribute to shaping the character of the teens themselves than support from friends and school. The preventive efforts against premarital sex that can be done are: not dating, be selective in friendship, strengthen their faith and prayers, limiting the friendship, being in a relationship only for good reasons, not watching porn, avoid opposite-sex friends with bad manners, not coming home late at night, being resolute over their principles, learn the danger of premarital sex behavior, widen their social network, and being more active in social activities and hobbies.
\end{abstract}

Keywords: preventive action, premarital sex, adolescents

Abstrak: Jumlah remaja yang melakukan hubungan seks di luar nikah mengalami trend peningkatan. Berdasarkan catatan lembaga BKKBN (2014), 46 \% remaja berusia 15-19 tahun sudah berhubungan seksual. Diperlukan suatu upaya perilaku pencegahan dalam mengatasi permasalahan meningkatnya seks pranikah di kalangan remaja. Tujuan dari penelitian ini adalah untuk mengidentifikasi faktor social support yang mendorong perilaku pencegahan seks pranikah pada remaja SMA X di Kota Surabaya. Jenis penelitian ini adalah deskriptif, dengan pendekatan kualitatif. Wawancara mendalam dilakukan kepada 32 informan yaitu 10 siswa, 10 teman sebaya, 10 orang tua, dan 2 guru. Hasil penelitian menunjukkan bahwa dukungan sosial terutama dari keluarga yang memberikan pendidikan agama, berkontribusi untuk membentuk karakter remaja itu sendiri dibandingkan dukungan dari teman dan sekolah. Upaya perilaku pencegahan seks pranikah yang didapatkan, yaitu: tidak pacaran, harus pintar memilih pergaulan yang baik, lebih memperkuat iman dan memperbanyak ibadah, membatasi pertemanan, jika mempunyai pacar hanya untuk penyemangat belajar, tidak melihat film porno, jangan mencari teman laki-laki yang mempunyai perilaku buruk, tidak pulang larut malam, lebih konsisten dengan prinsip pada diri sendiri, menambah pengetahuan tentang bahaya perilaku seks pranikah, memperluas pergaulan, dan aktif dalam melakukan kegiatan sosial dan hobi.

Kata kunci: perilaku pencegahan, seks pranikah, remaja

\section{PENDAHULUAN}

Masa remaja merupakan masa yang penuh gejolak emosi dan ketidakseimbangan sehingga menyebabkan mudah sekali terkena pengaruh dari lingkungan. Munculnya kekecewaan dan penderitaan; meningkatnya konflik dan pertentangan krisis penyesuaian; impian dan khayalan; pacaran dan percintaan; serta keterasingan dari kehidupan dewasa dan norma kebudayaan sering sekali membuat remaja bimbang (Gunarsa, 2008).

Munculnya permasalahan yang dialami remaja membuatnya mudah terjerumus pada perilaku menyimpang, seperti kriminalitas, minum minuman keras, penggunaan obat 
terlarang, tawuran, serta perilaku seks pranikah (Yusuf, 2011). Perilaku seks pranikah semakin meluas dan menjadi pembahasan serta perbincangan yang prioritas, selama beberapa tahun terakhir.

Penelitian Fajar (2015) menjelaskan bahwa perilaku seks pranikah merupakan hal yang sudah umum dalam kehidupan remaja. Infodatin (2014), seks aktif pranikah pada remaja berisiko terhadap kehamilan dan penularan penyakit menular seksual. Kehamilan yang tidak diinginkan dapat berlanjut pada aborsi dan pernikahan remaja. Keduanya akan berdampak tidak hanya pada masa depan remaja, namun juga janin yang dikandung, serta keluarga dari remaja tersebut.

Survei Demografi Kesehatan Indonesia (SDKI) 2012, menunjukkan 48 dari 1000 kehamilan di perkotaan adalah kelompok remaja usia 15-19 tahun. Angka ini meningkat dibandingkan dengan penemuan SDKI 2007 yang hanya 35 dari 1.000 kehamilan. Meningkatnya kehamilan remaja, salah satu faktor penyebabnya karena perilaku seks bebas. Sedangkan berdasarkan Riskesdas (2013), angka kehamilan penduduk perempuan usia 10-54 tahun adalah 2,68\%. Meskipun sangat kecil, namun terdapat kehamilan pada umur kurang dari 15 tahun yaitu sebesar $0,02 \%$ dan kehamilan pada umur remaja (15-19 tahun) sebesar $1,97 \%$.

Terjadi trend peningkatan pada jumlah remaja yang melakukan hubungan seks di luar nikah. Berdasarkan catatan lembaga BKKBN, 46\% remaja berusia 15-19 tahun sudah berhubungan seksual. Sedangkan Data Sensus Nasional menunjukkan bahwa 48-51\% perempuan hamil adalah remaja. Meningkatnya kasus remaja dalam perilaku hubungan seks berarti semakin pentingnya pendidikan reproduksi bagi anak.

Remaja usia SMP dan SMA beranggapan bahwa melakukan hubungan seksual sudah biasa, dan tidak lagi menakutkan. Hasil penelitian Komnas tahun 2012 tentang perilaku seks di kalangan remaja SMP dan SMA yang dilakukan di 17 kota besar di Indonesia menyebutkan bahwa dari 4.726 responden, 97\% mengatakan pernah menonton pornografi, $93,7 \%$ mengaku sudah tidak perawan, serta $21,26 \%$ sudah pernah melakukan aborsi. Persentase ini mengalami peningkatan dibandingkan penelitian yang juga dilakukan oleh Komnas tahun 2008 dengan jumlah responden yang sama. Komnas menemukan bahwa $62,7 \%$ remaja SMP sudah tidak perawan serta 21,2\% mengaku pernah melakukan aborsi.

Adanya peningkatan hasil penelitian yang telah dilakukan oleh Komnas tahun 2008 ke 2012 disebabkan karena kemudahan dalam mengakses tayangan media online yang banyak menampilkan pornografi. Kemudahan akses online membuat remaja dapat mengakses situs pornografi secara bebas. Situs pornografi yang dilihat membuat remaja ketagihan, selain itu tidak adanya kontrol dari keluarga dan minimnya pendidikan tentang reproduksi membuat kejadian seks bebas pada remaja semakin meningkat.

Dampak dari meningkatnya jumlah remaja yang melakukan hubungan seks yaitu meningkatnya angka kejahatan seksual yang dilakukan oleh anak-anak dan remaja. Kasus kejahatan seksual yang dilaporkan kepada Komnas Anak pada tahun 2013, dari 3.339 kasus sejumlah 58\% adalah kasus kejahatan seksual dan $16 \%$ pelakunya merupakan anak-anak (BKKBN, 2014).

Rahyani dkk (2012), menyatakan bahwa hubungan seksual sebelum menikah pada remaja menjadi masalah yang serius. Hal ini berhubungan dengan meningkatnya kasus penularan penyakit menular seksual, mempunyai pasangan lebih dari satu, dan kehamilan dini. Pajanan pornografi, perilaku langsung dan tidak langsung berhubungan secara signifikan dengan inisiasi hubungan seksual sebelum menikah. Remaja perempuan tampaknya melakukan lebih sedikit aktivitas seksual daripada remaja laki-laki.

Bentuk perilaku seks pranikah yang dilakukan oleh remaja SLTA di Kota Mojokerto, berdasarkan penelitian Isti'anah (2014) adalah bergandengan, ciuman, bercumbu, sampai pada melakukan senggama dengan lawan jenis. Perilaku itu dilakukan oleh remaja di waktu ada kesempatan dan lokasi yang tepat. Remaja melakukan perilaku seks pranikah di tempat-tempat yang sepi, seperti tempat wisata, rumah, hotel, villa, kamar kost, 
dan penginapan. Berbagai motif yang dikemukakan remaja antara lain: adanya dorongan biologis yang tidak terkontrol, adanya keinginan untuk mengaktualisasikan rasa cinta (afeksi) melalui hubungan seksual, adanya kebutuhan akan uang untuk pemenuhan hidup, dan adanya rasa ingin tahu yang berlebihan.

Sepanjang tahun 2015 terjadi peningkatan kasus kehamilan tidak direncanakan di kalangan pelajar Jawa Timur, yaitu sebanyak 30 kasus yang sebelumnya di tahun 2014 hanya ada 23 kasus. Ketua Divisi Data dan Riset Lembaga Perlindungan Anak (LPA) Jawa Timur menyebutkan bahwa usia pelajar yang mengalami kehamilan tidak diinginkan di wilayah Surabaya yaitu antara 12-18 tahun (Ayodhyaputri, 2015).

Penelitian dari Sari dan Muis (2014), didapatkan bentuk perilaku seksual remaja yaitu: berpegangan tangan (90\%), berpelukan $(78 \%)$, berciuman $(75 \%)$, meraba bagian tubuh yang sensitif (56\%), petting (37\%), oral seks (33\%), berhubungan seksual (27\%), serta kekerasan seksual (25\%). Salah satu penyebab meningkatnya kasus kehamilan yang tidak diinginkan oleh remaja adalah adanya perilaku seks pranikah. Pencegahan perilaku seks pranikah dapat dilakukan oleh remaja jika remaja mempunyai pengetahuan dan sikap yang baik.

Secara garis besar, risiko kesehatan remaja meliputi: (1) risiko biomedik (biomedical risks) seperti riwayat imunisasi, riwayat kesehatan keluarga, suhu badan, tinggi badan, berat badan, kolesterol, dan tekanan darah. (2) Risiko fisik (physical risks) seperti kebugaran, body image (penampilan), kebiasaan makan, risiko trauma yang tidak disengaja atau kecelakaan, trauma yang terkait dengan kekerasan atau kenakalan remaja. (3) Risiko psikososial (psychosocial risks), yaitu hal-hal yang terkait dengan sekolah atau masalah belajar, hubungan antar teman, depresi atau bunuh diri, perlakuan salah (physical, sexual, emotional abuse). (4) Risiko penggunaan zat-zat terlarang (substance use) yaitu alkohol, rokok, obatobatan terlarang, penyalahgunaan resep dokter, dan penggunaan obat bebas atau over the counter (OTC) yang melebihi dosis. (5) Perilaku seksual (sexual behavior) yaitu sesuatu yang terkait dengan hubungan seksual (Soetjiningsih dkk, 2016).

Perilaku manusia dipengaruhi oleh banyak sekali faktor dan sulit dibatasi. Hal ini disebabkan karena perilaku itu sendiri merupakan hasil dari beberapa faktor yang berasal dari internal dan eksternal seorang individu (Notoatmodjo, 2012). Snehandu B. Kar (1983) mengemukakan bahwa perilaku seseorang dapat dipengaruhi oleh berbagai faktor yaitu behavior intention (niat seorang untuk bertindak), social support (dukungan sosial dari teman, sekolah, dan keluarga di lingkungan sosial), accessibility of information (ada atau tidak adanya informasi yang mempengaruhi perilaku pencegahan seks pranikah), personal autonomy (otonomi pribadi dalam hal mengambil keputusan untuk melakukan perilaku pencegahan seks pranikah), dan action situation (situasi yang memungkinkan remaja untuk melakukan perilaku pencegahan seks pranikah).

Taylor (2012) menjelaskan bahwa dukungan sosial adalah informasi dari orang yang dicintai dan dipedulikan, dihormati dan dihargai, serta bagian dari hubungan dan kewajiban bersama. Dukungan sosial dapat berasal dari orang tua, pasangan, keluarga, teman, masyarakat, serta komunitas. Orangorang terdekat yang dicintai dan dihormati akan lebih memberikan manfaat kepada individu dalam memberikan dukungan sosial.

Tujuan dari penelitian ini adalah untuk melihat dukungan sosial (social support) yang mendorong perilaku pencegahan seks pranikah pada remaja SMA X di Kota Surabaya.

\section{METODE}

Jenis penelitian ini adalah deskriptif, dengan pendekatan kualitatif. Jenis penelitian ini mampu menangkap berbagai informasi kualitatif dengan deskriptif yang penuh nuansa dan lebih berharga dari sekedar pernyataan jumlah, maupun frekuensi dalam bentuk angka tanpa berusaha melakukan hipotesa. Penelitian kualitatif berakar pada latar alamiah sebagai suatu keutuhan, manusia sebagai alat penelitian yang bisa diandalkan, lebih mementingkan 
proses daripada hasil, membatasi kriteria untuk memberikan keabsahan serta hasil penelitiannya disepakati oleh kedua belah pihak yaitu peneliti dan informan. Pada penelitian kualitatif ini menggunakan pendekatan fenomenologis, yaitu peneliti berusaha memahami arti peristiwa dan kaitannya dengan orang-orang biasa dalam situasi tertentu (Moleong, 2002).

Populasi yang digunakan adalah siswa kelas XI atau 2 dari salah satu SMA yang menjadi mitra Sebaya PKBI Jawa Timur di kota Surabaya. Informan dalam penelitian ini sejumlah 32 orang, yang terdiri dari 10 remaja siswa SMA dan 22 orang sebagai informan untuk triangulasi sumber (10 orang tua, 10 teman sebaya, dan 2 guru).

Kriteria inklusi untuk pemilihan informan siswa yaitu: remaja siswa SMA kelas 2, aktif dalam organisasi di sekolah (OSIS) dan atau di luar sekolah, serta bersedia menjadi informan. Selanjutnya, kriteria inklusi untuk teman sebaya yaitu: mengenal informan $\geq 3$ bulan, intensitas bertemu dengan informan $>3 x$ dalam seminggu, sering diajak diskusi atau teman curhat dalam 1 bulan terakhir ini, serta bersedia menjadi informan.

Informan guru yaitu guru Bimbingan Konseling (BK) yang bertanggung jawab atas perkembangan siswa di sekolah serta guru kelas. Pemilihan guru kelas dan guru bimbingan konseling (BK) sebagai informan disebabkan karena guru tersebut secara langsung berinteraksi dengan remaja yang sudah dipilih sebelumnya berdasarkan masukan dari wakil kepala sekolah bagian kesiswaan. Informan orang tua didapatkan atas dasar pertimbangan salah satu orang tua (bisa ayah, ibu atau yang bertanggung jawab atas perkembangan informan di rumah). Lokasi penelitian ini dilakukan di salah satu SMA swasta di Surabaya yang menjadi mitra Sebaya PKBI Jawa Timur. Waktu pelaksanaan penelitian dilaksanakan pada bulan Juni 2016 hingga Februari 2017.

Data yang digunakan dalam penelitian terbagi menjadi 2 (dua), yaitu (1) data primer merupakan data yang diambil secara langsung dengan cara wawancara mendalam (indepth interview) yang menggunakan panduan pedoman wawancara dan (2) data sekunder yang diperoleh dari sumber tertulis, misalnya tata tertib dan peraturan sekolah. Instrumen yang digunakan adalah pedoman wawancara untuk informan yang terpilih dan format panduan wawancara mendalam.

Beberapa cara pengumpulan data yaitu persiapan, pengumpulan data, analisis data, penyusunan laporan penelitian yang dibagi menjadi 4 (empat) tahapan, yaitu: menyusun laporan awal, mendiskusikan laporan yang telah disusun dengan pembimbing dan orang yang memahami penelitian, melakukan perbaikan proposal sesuai dengan hasil diskusi, dan menyusun laporan akhir penelitian.

Pada saat menganalisis data, penulis berusaha untuk memberikan arti yang signifikan terhadap analisis, menjelaskan pola uraian, serta mencari hubungan di antara berbagai dimensi uraian (Arikunto, 2002). Langkah selanjutnya jika data telah terkumpul adalah mengolah, menganalisa dan mengambil kesimpulan dari data yang telah terkumpul. Tujuan analisa data adalah untuk memfokuskan dan membatasi berbagai penemuan sehingga menjadi data yang teratur dan tersusun secara rapi dan berarti. Teknik analisa data yang digunakan adalah analisis interaktif. Tahapan analisis datanya yaitu, pengumpulan data, reduksi data, sajian data, serta verifikasi atau penarikan kesimpulan.

Kredibilitas dan validitas data dalam penelitian, digunakan triangulasi sumber dan menggunakan bahan referensi bisa berupa dokumentasi. Dalam triangulasi sumber, digunakan teknik pengumpulan data yang sama untuk mendapatkan data dari sumber-sumber yang berbeda (Sugiyono, 2013). Validitas data dilakukan dengan cara membandingkan dan mengecek data yang telah didapatkan dari hasil wawancara melalui beberapa informan atau key informan. Bahan referensi yang digunakan dalam penelitian ini adalah adanya pendukung untuk membuktikan data yang telah ditemukan oleh peneliti.

Pendekatan triangulasi sumber dimulai dengan cara mengumpulkan data dari berbagai pihak sumber yang mencangkup pendapat dan pandangan siswa SMA kemudian teman dekat atau sebaya, guru, serta orang tua. Hal ini untuk mengecek 
kepercayaan atau suatu informasi yang diperoleh melalui teknik pengumpulan data yang sama. Bahan referensi dalam penelitian meliputi rekaman wawancara, field note (catatan lapangan), dan foto-foto kegiatan penelitian sehingga menjadi lebih dapat dipercaya.

\section{HASIL PENELITIAN}

Berdasarkan data hasil penelitian, didapatkan jumlah informan sebanyak 10 orang siswa yang sedang duduk di kelas sebelas atau dua di SMA X Kota Surabaya. Sebagian besar informan adalah perempuan, dengan usia antara 15-17 tahun. Agama dari sebagian besar informan adalah Islam. $>$ Rp 3.000.000,- per bulan, dengan jumlah uang saku informan antara Rp 5.000,- hingga $\mathrm{Rp}$ $20.000,-$. Data yang lebih rinci mengenai karakteristik informan dapat dilihat pada Tabel 1.

Dukungan sosial (social support) didapatkan dari dukungan yang telah diberikan oleh teman sebaya, keluarga serta guru yang ada di sekolah informan. Adanya dukungan dari teman sebaya, orang tua (keluarga), dan guru memberikan peranan bagi informan untuk berperilaku. Berdasarkan hasil wawancara mendalam dengan informan untuk triangulasi, didapatkan berbagai macam jawaban terkait dukungan sosial yang telah diberikan.

Dukungan sosial dari teman sebaya mempunyai peranan yang cukup penting dalam perilaku pencegahan seks pranikah bagi remaja. Informan dalam lingkungan pertemanan seluruhnya adalah teman dekat remaja yang mengenal informan $\geq 3$ bulan, intensitas bertemu dengan informan $>3 \mathrm{x}$ dalam seminggu, sering diajak diskusi atau teman curhat dalam 1 bulan terakhir, serta bersedia menjadi informan. Berdasarkan hasil wawancara mendalam dengan teman sebaya didapatkan uraian tentang dukungan sosial yang diberikan pada remaja terdapat dalam Tabel 2.

Tabel 2. Dukungan Sosial dari Lingkungan Pertemanan (Teman Sebaya)

\begin{tabular}{lll}
\hline \multicolumn{1}{c}{$\begin{array}{c}\text { Dukungan } \\
\text { Sosial }\end{array}$} & \multicolumn{1}{c}{$\begin{array}{c}\text { Bentuk } \\
\text { dukungan }\end{array}$} & $\begin{array}{c}\text { Jumlah } \\
\text { Teman } \\
\text { Sebaya }\end{array}$ \\
\hline Mendukung & $\begin{array}{l}\text { Saling } \\
\text { memberikan } \\
\text { nasihat, sharing } \\
\text { tentang masa } \\
\text { depan dan } \\
\text { mengajak ke arah } \\
\text { pergaulan yang } \\
\text { baik. }\end{array}$ & \\
\cline { 2 - 3 } & $\begin{array}{l}\text { Saling } \\
\text { mengingatkan } \\
\text { dalam } \\
\text { berperilaku dan } \\
\text { memilih teman. }\end{array}$ & \\
\hline Tidak & \multicolumn{1}{c}{3} \\
\hline mendukung & & 0 \\
\hline
\end{tabular}

Berdasarkan Tabel 2 menunjukkan bahwa seluruh teman sebaya dari informan mendukung adanya perilaku pencegahan seks pranikah bagi remaja. Sebagian besar bentuk dukungan yang diberikan yaitu

Tabel 1. Karakteristik Informan

\begin{tabular}{|c|c|c|c|c|c|c|}
\hline Informan & Inisial & $\begin{array}{c}\text { Jenis } \\
\text { Kelamin }\end{array}$ & Usia & Agama & $\begin{array}{c}\text { Pendapatan Orang } \\
\text { Tua (per bulan) }\end{array}$ & Uang Saku (per hari) \\
\hline Informan 1 & ELH & $\mathrm{P}$ & 17 & Islam & $\pm \mathrm{Rp} 4.000 .000,-$ & Rp 10.000,- \\
\hline Informan 2 & AYS & $\mathrm{L}$ & 16 & Islam & $>$ Rp 5.000.000,- & Rp 10.000,- \\
\hline Informan 3 & FTI & $\mathrm{P}$ & 16 & Islam & $\pm \operatorname{Rp} 5.000 .000,-$ & $\operatorname{Rp} 20.000,-$ \\
\hline Informan 4 & UMS & $\mathrm{P}$ & 15 & Islam & $\pm \mathrm{Rp} 3.000 .000,-$ & Rp 15.000,- \\
\hline Informan 5 & DNF & $\mathrm{P}$ & 17 & Islam & $\pm \operatorname{Rp} 4.000 .000,-$ & Rp 10.000,- \\
\hline Informan 6 & JSK & $\mathrm{P}$ & 16 & Islam & $\pm \mathrm{Rp} 3.000 .000,-$ & Rp 15.000,- \\
\hline Informan 7 & NIS & $\mathrm{P}$ & 15 & Kristen & $>$ Rp 3.000.000,- & Rp 15.000,- \\
\hline Informan 8 & NHR & $\mathrm{L}$ & 16 & Islam & $>$ Rp 3.000.000,- & $\mathrm{Rp} 10.000,-$ \\
\hline Informan 9 & YDE & $\mathrm{P}$ & 16 & Kristen & $\pm \operatorname{Rp} 5.000 .000,-$ & Rp 5.000,- s/d Rp 10.000,- \\
\hline Informan 10 & JLW & $\mathrm{P}$ & 16 & Katolik & $\pm \mathrm{Rp} 3.000 .000,-$ & Rp $10.000,-$ s/d Rp 15.000,- \\
\hline
\end{tabular}


saling memberikan nasihat sharing tentang masa depan dan mengajak ke arah pergaulan yang baik, sebanyak tujuh orang informan. Contoh cuplikan kuotasi berdasarkan wawancara mendalam yaitu:

"Mendukung. Itu kayak memberi contoh-contoh yang udah terjadi. Itu kan uda ada pengalaman-pengalaman dari temen-temennya yang terkena gitu. Terus kan kayak ada cerita-cerita gitu, kita gosip terus saling ngasih (memberi) nasihat. Terus kan kalo kita biasanya dapat materi dari seminar dari sekolah, biasanya diceritain gitu." (ELN, 16 tahun)

Selanjutnya, bentuk dukungan lainnya yang diberikan oleh teman sebaya yaitu saling mengingatkan dalam berperilaku dan memilih teman sebanyak tiga orang key informan. Contoh cuplikan kuotasi berdasarkan wawancara mendalam yaitu:

"Mendukung, mengingatkan selalu pastinya. Ya kalau misalkan mungkin dia punya pacar ya mengingatkan jangan melebihi batas, lebih berhatihati saja. Apa kalau misal bergaul milih temen yang baik, biar nggak terjerumus ke hal-hal yang nggak baik gitu Kak. Uda itu aja. Hal yang nggak baik itu misale kayak sekx bebas, narkoba, gitugitu lah pokoknya..." (ZAH, 17 tahun)

Bentuk dukungan yang diberikan teman sebaya kepada informan secara keseluruhan agar remaja melakukan perilaku pencegahan seks pranikah.

Orang tua memegang peranan penting dalam memberikan pengaruh terhadap perkembangan jiwa remaja. Hal ini karena peran orang tua sebagai titik awal proses identifikasi diri untuk remaja. Oleh karena itu, dukungan sosial yang diberikan orang tua kepada informan remaja sangat diperlukan. Berikut disajikan data terkait dukungan sosial yang diberikan orang tua kepada informan remaja.

Berdasarkan Tabel 3, seluruh orang tua atau keluarga mendukung remaja dalam perilaku pencegahan seks pranikah. Sebagian dari orang tua memberikan bentuk dukungan dengan mengarahkan dan mengingatkan informan agar tidak salah pergaulan. Berikut merupakan salah satu contoh cuplikan
Tabel 3. Dukungan Sosial dari Lingkungan Keluarga (Orang Tua)

\begin{tabular}{lll}
\hline $\begin{array}{c}\text { Dukungan } \\
\text { Sosial }\end{array}$ & \multicolumn{1}{c}{$\begin{array}{c}\text { Bentuk } \\
\text { Dukungan }\end{array}$} & $\begin{array}{c}\text { Jumlah } \\
\text { Key } \\
\text { Informan }\end{array}$ \\
\hline Mendukung & $\begin{array}{l}\text { Mengarahkan } \\
\text { anak tentang } \\
\text { masalah seks } \\
\text { pranikah } \\
\text { dan selalu } \\
\text { mengingatkan } \\
\text { anak agar tidak } \\
\text { salah pergaulan }\end{array}$ & \\
\cline { 2 - 3 } & $\begin{array}{l}\text { Mengajarkan } \\
\text { ibadah dan } \\
\text { memberikan } \\
\text { nasihat untuk } \\
\text { lebih tekun } \\
\text { beribadah } \\
\text { sebagai upaya } \\
\text { pencegahan seks } \\
\text { pranikah }\end{array}$ \\
\hline Tidak & 5 \\
mendukung & - \\
\hline
\end{tabular}

kuotasi dari hasil wawancara mendalam mengenai dukungan sosial orang tua yang pertama, yaitu:

"Kayak dikasih pengarahan, dalam keluarga dikasih pengertian masalah seks pranikah seperti ini akibatnya seperti ini, biar dia tau, kalau dia tau kan dia nggak cari tau ke temantemannya, kan teman-temannya lebih berbahaya. Nanti kalo dikasih tau temennya, cara penyampaiannya salah nanti kan takutnya, takutnya. Ya dikasih tau supaya dia nggak sampek terjerumus seperti itu mbak. Jangan sampai terjadi seks pranikah. Kan nanti akibatnya juga dia sendiri yang susah." (EYN, 37 tahun)

Hasil wawancara mendalam lainnya didapat bahwa bentuk dukungan sosial oleh orang tua kepada remaja sebagian yang lain dengan mengajarkan agama kepada remaja serta memberikan nasihat. Salah satu contoh cuplikan kuotasi mengenai dukungan sosial orang tua yang diberikan kepada informan yaitu:

“... Disini ini tempatnya anak-anak nakal semuanya disini... Tapi anak saya nggak tau srawung (berkumpul), 
semuanya ndak (tidak) mau, yang besar dulu disini juga. Tapi anak saya nggak mau kumpul sama anak-anak yang disini, semuanya tiga-tiganya itu ndak mau. Kan bapaknya imam masjid sini, disegani orang banyak, kan malu, gitu barangkali ya anak saya. Jadi saya cuma bilang aja, jangan sampek bergaul sama anak-anak ya. Pokoknya harus sholat tekun itu nomor 1. Bapaknya tiap hari, kalo sholat itu wes tha, ditanyain terus. Ditanyain tata krama sopan santun, sering ditanyain." (SRF, 50 tahun).

Informan dalam lingkungan keluarga sebagian besar adalah Ibu informan. Seluruh orang tua memberikan dukungan kepada remaja dalam perilaku pencegahan seks pranikah.

Dukungan sosial dari lingkungan sekolah didapatkan melalui wawancara mendalam ke guru kelas dan guru BK sebagai salah satu informan. Berdasarkan hasil wawancara tentang dukungan sosial yang sekolah berikan untuk remaja SMA berkaitan dengan perilaku pencegahan seks pranikah. Berikut data lebih rinci pada Tabel 4.

Selain itu berdasarkan hasil wawancara mendalam lainnya, didapatkan upaya perilaku pencegahan seks pranikah pada remaja SMA X di Kota Surabaya. Informan memberikan jawaban yang berbeda-beda, namun beberapa diantaranya juga memiliki kesamaan. Dimulai dari jawaban terbanyak, upaya perilaku pencegahan seks pranikah dapat dilihat pada Tabel 5.

Adanya upaya yang dilakukan oleh informan menunjukkan bahwa informan melakukan perilaku pencegahan seks pranikah karena mengetahui seberapa penting hal tersebut untuk dilakukan.

\section{PEMBAHASAN}

Adanya dukungan sosial terhadap remaja juga menjadi faktor yang mempengaruhi seorang individu dalam perilaku pencegahan seks pranikah. Dukungan sosial menurut Taylor (2012) yaitu informasi dari orang yang dicintai dan dipedulikan, dihormati dan dihargai, serta bagian dari hubungan dan kewajiban bersama. Dukungan sosial yang diberikan
Tabel 4. Dukungan Sosial dari Lingkungan Sekolah (Guru)

\begin{tabular}{cl}
\hline $\begin{array}{c}\text { Dukungan } \\
\text { Sosial }\end{array}$ & \multicolumn{1}{c}{ Bentuk dukungan } \\
\hline Mendukung & $\begin{array}{l}\text { Mengadakan kegiatan } \\
\text { ekstrakurikuler olahraga, } \\
\text { seperti futsal, basket, dan } \\
\text { berbagai ketrampilan seperti } \\
\text { ketrampilan batik, sablon. } \\
\text { Sehingga remaja ketika } \\
\text { dirumah tidak berfikiran } \\
\text { tentang hal-hal yang negatif, } \\
\text { karena telah sibuk dengan } \\
\text { kegiatan positif lainnya di } \\
\text { sekolah. }\end{array}$ \\
\hline
\end{tabular}

\section{Lanjutan}

Tabel 4. Dukungan Sosial dari Lingkungan Sekolah (Guru)

\begin{tabular}{ll}
\hline $\begin{array}{c}\text { Dukungan } \\
\text { Sosial }\end{array}$ & \multicolumn{1}{c}{ Bentuk dukungan } \\
\hline Mendukung & $\begin{array}{l}\text { Mengikutsertakan siswa } \\
\text { siswi dalam seminar maupun } \\
\text { penyuluhan tentang kesehatan } \\
\text { dari Puskesmas, sekolah lain, } \\
\text { maupun Dinas Kesehatan. }\end{array}$ \\
\cline { 2 - 2 } & $\begin{array}{l}\text { Memberikan materi pelajaran } \\
\text { di kelas tentang masalah } \\
\text { reproduksi maupun kenakalan } \\
\text { remaja. }\end{array}$ \\
\cline { 2 - 2 } & $\begin{array}{l}\text { Bekerjasama dengan sebaya } \\
\text { PKBI Jawa Timur untuk } \\
\text { memberikan sosialisasi }\end{array}$ \\
& $\begin{array}{l}\text { berkaitan dengan masalah } \\
\text { kesehatan remaja. }\end{array}$ \\
\hline Tidak & $\begin{array}{l}\text { Razia HP dilakukan tidak } \\
\text { secara rutin setiap bulan } \\
\text { mendukung }\end{array}$ \\
& (belum maksimal dan efektif) \\
\hline
\end{tabular}

Tabel 5. Upaya Perilaku Pencegahan Seks Pranikah pada Remaja SMA

\begin{tabular}{lc}
\hline \multicolumn{1}{c}{ Upaya } & $\begin{array}{c}\text { Jumlah } \\
\text { Informan }\end{array}$ \\
\hline $\begin{array}{l}\text { Tidak pacaran. } \\
\text { Harus pintar memilih pergaulan } \\
\text { yang baik. }\end{array}$ & 5 \\
$\begin{array}{l}\text { Lebih memperkuat akidah } \\
\text { atau iman dan memperbanyak } \\
\text { ibadah. } \\
\begin{array}{l}\text { Membatasi pertemanan } \\
\text { khususnya dengan lawan jenis. }\end{array}\end{array}$ & 3 \\
\hline
\end{tabular}




\section{Lanjutan}

Tabel 5. Upaya Perilaku Pencegahan Seks Pranikah pada Remaja SMA

\begin{tabular}{lc}
\hline \multicolumn{1}{c}{ Upaya } & $\begin{array}{c}\text { Jumlah } \\
\text { Informan }\end{array}$ \\
\hline $\begin{array}{l}\text { Aktif dalam melakukan } \\
\text { kegiatan sosial, outbound, } \\
\text { traveling bersama keluarga, dan } \\
\text { menyalurkan hobi (olahraga). }\end{array}$ & 2 \\
$\begin{array}{l}\text { Jika mempunyai pacar hanya } \\
\text { untuk penyemangat belajar. }\end{array}$ & 1 \\
$\begin{array}{l}\text { Tidak melihat film porno. } \\
\text { Jangan mencari teman laki- } \\
\text { laki yang mempunyai perilaku } \\
\text { buruk. }\end{array}$ & 1 \\
$\begin{array}{l}\text { Tidak pulang larut malam, diatas } \\
\text { jam 21.00 WIB. }\end{array}$ & 1 \\
$\begin{array}{l}\text { Lebih konsisten dengan prinsip } \\
\text { pada diri sendiri. }\end{array}$ & 1 \\
$\begin{array}{l}\text { Menambah pengetahuan tentang } \\
\text { bahaya perilaku seks pranikah. } \\
\text { Memperluas pergaulan, sehingga } \\
\text { dapat memahami beberapa } \\
\text { karakter teman. }\end{array}$ & 1 \\
\hline
\end{tabular}

sebagian besar orang terdekat dan orang yang dicintai serta dihormati akan lebih bermanfaat untuk individu daripada dukungan sosial yang diberikan oleh orang asing atau yang memiliki hubungan jauh. Menurut Sarafino (2006), dukungan sosial dapat berasal dari berbagai sumber, yaitu suami atau istri (pasangan), keluarga, teman, rekan kerja, dokter, dan komunitas.

Dukungan sosial yang diberikan untuk remaja dapat berasal dari lingkungan pertemanan yang diberikan oleh teman sebaya, lingkungan keluarga atau sekitar tempat tinggal yang diberikan oleh orang tua, serta dukungan sosial dari lingkungan sekolah yang diberikan oleh guru maupun tata tertib yang ada dalam sekolah. Seluruh teman sebaya, orang tua, guru maupun sekolah memberikan dukungan sosial terhadap perilaku pencegahan seks pranikah remaja, namun bentuk dukungan yang diberikan berbeda.

Santrock (2003) menyatakan bahwa teman sebaya merupakan anak-anak atau remaja yang memiliki tingkat usia atau kedewasaan yang sama. Pengaruh teman sebaya dalam pengembangan dan pembentukan identitas diri seorang individu remaja tidak bisa dianggap tidak penting. Hal ini karena remaja biasanya menghabiskan waktu untuk saling bertukar informasi tentang dunia luar dengan teman sebaya. Hal ini berpengaruh pada pemikiran remaja dalam mengembangkan siapa dirinya dan apa yang harus dilakukan untuk menjadi seseorang.

Bentuk dukungan yang diberikan teman sebaya sebagian besar yaitu saling memberikan nasihat, sharing tentang masa depan dan mengajak ke arah pergaulan yang baik. Sedangkan teman sebaya yang lain menyatakan bentuk dukungannya dengan saling mengingatkan dalam berperilaku dan memilih teman. Adanya peranan teman sebaya dalam dukungan sosial kepada remaja, tentunya akan mempengaruhi pemikiran dan perilaku remaja dalam perilaku pencegahan seks pranikah.

Hal ini sejalan dengan penelitian yang telah dilakukan oleh Darmayanti dkk (2011) di enam Sekolah Lanjutan Tingkat Atas (SLTA) Kota Bukittinggi dengan populasi seluruh siswa SLTA kelas XI dan XII sebanyak 276 orang. Darmayanti dkk menyatakan bahwa lebih dari separuh teman sebaya berperan aktif dalam memberikan informasi mengenai kesehatan reproduksi dan perilaku seksual. Adanya hubungan antara peran teman sebaya positif dengan perilaku seks pranikah yaitu responden yang mempunyai teman sebaya pasif berpeluang untuk berperilaku seks pranikah dibandingkan responden yang mempunyai teman sebaya aktif. Hal ini menunjukkan bahwa teman sebaya memberikan pengaruh yang cukup banyak terhadap perilaku remaja.

Bentuk dukungan teman sebaya dalam perilaku pencegahan seks pranikah pada remaja yaitu melalui nasihat. Salah satu teman sebaya menyatakan bahwa bentuk dukungan yang diberikan yaitu melalui contoh kejadian teman-teman yang melakukan perilaku seks pranikah. Teman sebaya saling mengingatkan dan memberikan nasihat satu sama lain. Hal ini juga disampaikan oleh remaja bahwa bentuk dukungan yang diberikan teman sebaya yaitu dengan saling memberikan nasihat satu sama lain melalui beberapa 
kejadian tentang seks pranikah yang terjadi di lingkungan sekitar tempat tinggal maupun dari berita media sosial.

Selanjutnya bentuk dukungan yang diberikan teman sebaya kepada remaja yaitu saling mengingatkan dalam berperilaku dan memilih teman. Salah satu teman sebaya menjelaskan bahwa dukungan sosial yang diberikan dengan saling mengingatkan untuk tidak berpacaran yang melebihi batas, lebih berhati-hati dalam pergaulan, serta harus pandai dalam memilih teman yang baik. Teman sebaya tidak ingin jika temannya salah dalam memilih pergaulan. Hal ini juga disampaikan oleh remaja bahwa dirinya bersama temannya selalu saling memberikan dukungan dengan mengingatkan agar tidak terjerumus ke pergaulan yang salah, seperti perilaku seks pranikah.

Orang tua memegang peranan penting dalam memberikan pengaruh terhadap perkembangan jiwa remaja. Hal ini karena, peranan orang tua merupakan titik awal proses identifikasi diri bagi remaja. Oleh karena itu dukungan sosial yang diberikan orang tua kepada remaja sangat diperlukan dalam menentukan perilaku remaja.

Bentuk dukungan yang diberikan orang tua kepada remaja yaitu dengan mengarahkan anak tentang masalah seks pranikah dan selalu mengingatkan agar tidak salah pergaulan, serta mengajarkan ibadah dan memberikan nasihat untuk lebih tekun beribadah. Hal ini merupakan suatu upaya orang tua dalam pencegahan seks pranikah bagi anak-anak. Sebagian dari orang tua memberikan bentuk dukungan dengan mengarahkan dan mengingatkan agar tidak salah pergaulan. Arahan tersebut dapat berupa penjelasan mengenai masalah seks pranikah seperti pengertian dan akibat yang akan terjadi, sehingga remaja mengetahui informasi tentang seks pranikah dari orang yang tepat yaitu orang tua. Orang tua lebih merasa khawatir jika anak mereka mendapatkan informasi melalui temantemannya. Menurut orang tua, teman sebaya dapat memberikan penjelasan yang salah kepada anak tentang seks pranikah. Sebagian orang tua lainnya memberikan dukungan kepada remaja dengan mengajarkan ibadah atau shalat untuk yang beragama islam sejak dari kecil, sehingga diharapkan remaja dapat mempunyai pondasi agama yang kuat ketika berada di lingkungan masyarakat.

Penelitian ini sejalan dengan hasil penelitian Haryani dkk (2015) terhadap 78 responden siswa kelas XII SMKN 1 Sedayu, bahwa mayoritas orang tua siswa mempunyai peran yang baik. Orang tua berperan dalam memberikan dasar pendidikan agama, menciptakan suasana rumah yang hangat dan menyenangkan, serta memberikan pemahaman akan norma baik dan buruk yang ada dalam masyarakat. Selain itu orang tua juga berperan dalam memberikan contoh yang baik bagi anak dengan penuh kasih sayang atau dengan cara bersahabat dengan anak agar anak merasa lebih nyaman. Adanya peran orang tua yang baik menunjukkan bahwa terdapat hubungan yang signifikan antara peran orang tua dengan perilaku seks pranikah remaja di SMKN 1 Sedayu.

Adanya pendidikan agama dalam keluarga memberikan kontribusi karakter dari remaja itu sendiri. Hal ini sebagai upaya dan dukungan keluarga dalam mendorong perilaku pencegahan seks pranikah pada remaja.

Pada lingkungan sekolah, remaja mendapatkan dukungan dalam perilaku pencegahan seks pranikah melalui pelajaran sekolah, ekstrakurikuler maupun tata tertib yang ada di sekolah. Sekolah merupakan tempat dimana remaja/siswa menghabiskan waktu lebih banyak selain di rumah. Sehingga guru berperan sebagai orang tua bagi siswa jika remaja sudah berada di sekolah. Menurut Muliyati (2012) guru menjadi fitur yang menempati posisi dan memegang peranan penting dalam pendidikan, terutama pendidikan yang berkaitan dengan kesehatan reproduksi. Adanya interaksi guru dengan siswanya dapat mempengaruhi siswa dalam perilaku pencegahan seks pranikah.

Selain bentuk dukungan yang mendukung adanya perilaku pencegahan seks pranikah diatas, terdapat pula bentuk dukungan lain dari sekolah berupa razia HP. Namun bentuk dukungan ini masih belum dijalankan secara maksimal oleh pihak sekolah karena adanya kegiatan lain di sekolah misalnya saat ada ujian UTS dan UAS, sehingga razia gadget tidak dilakukan. 
Hal ini juga berdasarkan dari wawancara mendalam yang dilakukan kepada guru bimbingan konselor (BK) sekolah, bahwa untuk razia gadget memang tidak dilakukan secara rutin. Razia gadget ini biasanya dilakukan jika ada siswa atau siswi yang diketahui bermasalah.

Pendidikan seks di sekolah telah dilakukan melalui kegiatan belajar mengajar. Menurut Yanne (2011) dalam artikel di BKKBN, selama ini beredar asumsi di kalangan masyarakat tentang pendidikan seks yang dianggap tabu. Asumsi tersebut menyatakan bahwa pendidikan seks sama dengan sosialisasi aktivitas seks dan identitas seks. Sebenarnya, apabila remaja mengetahui esensi dari pendidikan seks yang meliputi tentang pengetahuan genital, pemahaman mengenai organ-organ tubuh yang boleh dilihat atau tidak, bagaimana cara menjaga kesehatan organ reproduksi, dan batasan bergaul dengan teman lawan jenis, serta risiko yang mungkin dapat terjadi jika melakukan seks pranikah, maka remaja tidak akan berani untuk mencoba melakukan seks pranikah.

\section{KESIMPULAN}

Kesimpulan dari hasil penelitian ini yaitu lingkungan pertemanan, sekolah maupun keluarga memberikan dukungan dalam perilaku pencegahan seks pranikah. Bentuk dukungan dari teman sebaya yaitu saling memberikan nasihat. Sedangkan bentuk dukungan orang tua atau keluarga yaitu dengan mengarahkan dan mengingatkan agar tidak salah pergaulan, serta mengajarkan ibadah. Namun dalam lingkungan sekolah terdapat bentuk dukungan sosial yang kurang mendukung perilaku pencegahan seks pranikah pada remaja yaitu belum secara rutin dilakukan razia HP di sekolah. Bentuk dukungan dari teman, keluarga, dan sekolah memberikan pengaruh terhadap remaja, terutama keluarga dalam memberikan pendidikan agama yang memberi kontribusi karakter dari remaja itu sendiri. Upaya perilaku pencegahan seks pranikah pada remaja yang bisa dilakukan yaitu tidak pacaran, harus pintar memilih pergaulan yang baik khususnya dengan lawan jenis, serta aktif dalam melakukan kegiatan, seperti kegiatan sosial, outbound, traveling bersama keluarga, dan menyalurkan hobi (olahraga).

\section{SARAN}

Saran yang dapat diberikan berdasarkan penelitian ini yaitu, bagi remaja SMA diharapkan dapat memahami upaya perilaku pencegahan seks pranikah. Remaja SMA diharapkan dapat meningkatkan pemahaman tentang sex education agar tidak terhindar dari perilaku seks pranikah. Bagi teman sebaya, diharapkan dapat saling memberikan dukungan berupa nasihat yang mendukung perilaku pencegahan seks pranikah, serta mengajak remaja untuk aktif dalam kegiatan ekstrakurikuler di sekolah maupun kegiatan keagamaan atau sosial di lingkungan rumah. Bagi orang tua (keluarga), diharapkan orang tua dapat memberikan pengetahuan tentang agama sejak dini, menanamkan nilai-nilai norma yang ada di masyarakat, mengajak anak untuk menyibukkan diri dan aktif dalam kegiatan keagamaan atau sosial di masyarakat, serta memberikan edukasi tentang pendidikan seks sejak dini agar anak terhindar dari perilaku seks pranikah. Bagi sekolah, diharapkan pihak sekolah dapat mendukung remaja dalam perilaku pencegahan seks pranikah, diantaranya melalui peningkatan kegiatan keagamaan atau ekstrakurikuler dan pemberian sex education yang berguna untuk memberikan arahan kepada remaja dalam mencegah adanya perilaku seks pranikah di kalangan remaja SMA.

\section{DAFTAR PUSTAKA}

Arikunto, S. 2002. Prosedur Penelitian Suatu Pendekatan Praktek. Jakarta: PT. Rineka Cipta.

Ayodhyaputri, W. 2015. Kasus KTD Surabaya Terbesar se-Jawa Timur. Tersedia di $<$ http://www.samsaranews.com/kasusktd-surabaya-terbesar-se-jawa-timur/> [diakses tanggal 12 Juni 2016].

BKKBN. 2014. Remaja Pelaku Seks Bebas Meningkat. Jakarta : BKKBN. Tersedia $\mathrm{di}<\mathrm{http}$ ://www.bkkbn.go.id/ViewBerita. aspx?BeritaID $=1761>$ diakses tanggal 12 Juni 2016]. 
Darmayanti, Y., Lestari, Y., dan Ramadani, M. 2011. Peran Teman Sebaya Terhadap Perilaku Seksual Pranikah Siswa SLTA Kota Bukittinggi. Jurnal Kesehatan Masyarakat, 6 (1) : pp.24-27.

Fajar, N. A. 2015. Analisis Bio, Psiko, Sosial, dan Spiritual pada Perilaku Seks Bebas Remaja Muslim Religius di Palembang. Tesis. Universitas Airlangga.

Gunarsa, S. D. 2008. PsikologiPerkembangan Anak dan Remaja. Jakarta : Gunung Mulia.

Haryani, D. S., Wahyuningsih, dan Haryani, K. 2015. Peran Orang Tua Berhubungan dengan Perilaku Seksual Pranikah Remaja di SMKN 1 Sedayu. Jurnal Ners and Midwifery Indonesia, 3(3): pp.140-144

Infodatin. 2014. Situasi Kesehatan Reproduksi Remaja. Kementerian Kesehatan

Isti'anah, B. 2014. Seks Pranikah Dikalangan Remaja: Studi Kasus Pelajar SLTA Kota Mojokerto. Undergraduate Thesis. UIN Sunan Ampel Surabaya.

Kemenkes RI, 2013. Riskesdas. Jakarta: Kemenkes RI.

Moleong, L.J. 2002. Metodologi Penelitian Kualitatif. Bandung: Remaja Rosda Karya.

Muliyati. 2012. Faktor-faktor yang Berhubungan dengan Perilaku Gaya Pacaran pada Siswa SMU X dan MAN Y Kabupaten Sidrap Propinsi Sulawesi Selatan Tahun 2012. Skripsi. Depok; Universitas Indonesia.
Notoatmodjo, S. 2010. Metodologi Penelitian Kesehatan. Jakarta: Rineka Cipta.

Notoatmodjo, S. 2012. Pendidikan dan Perilaku Kesehatan. Jakarta: Rineka Cipta.

Rahyani, K.Y., Utarini, A., Wilopo, S.A., dan Hakimi M. 2012. Perilaku Seks Pranikah Remaja. Tersedia di <http:// jurnalkesmas.ui.ac.id/index.php/kesmas/ article/view $/ 53>$ [diakses tanggal 12 Juni 2016].

Santrock, J.W. 2003 Adolescence: Perkembangan Remaja, edisi keenam. Jakarta: Erlangga.

Sari, R.T., dan Muis, T. 2014, Perilaku Seksual Remaja Siswa SMK Ketintang Surabaya, JurnalBK. 4(3): pp.1-9.

Soetjiningsih dan Ranuh, IG. N. Gde. 2016. Tumbuh Kembang Anak. Jakarta: EGC.

Sugiyono. 2013. Metode Penelitian Kuantitatif, Kualitatif, dan $R \& D$. Bandung: Alfabeta.

Taylor, S. E. 2012. Health Psychology. $8^{\text {th }}$. Ed. New York: McGraw-Hill Companies, Inc.

Yanne, R. 2011. Seks Bebas di Kalangan Remaja. Tersedia di $<$ http://kepri.bkkbn. go.id/Lists/Artikel/DispForm.aspx?ID=1 30\&ContentTypeId $=0 \mathrm{x} 01003 \mathrm{DCABAB}$ C04B7084595DA364423DE7897> [dia kses tanggal 25 Desember 2016].

Yusuf, S. 2011. Psikologi Perkembangan Anak dan Remaja. Bandung: Remaja Rosdakarya. 